\title{
Preference Reasons for Recreational Areas Which Belongs to the Local Administrations
}

\author{
Abdurrahman Kırtepe $^{1}$, Oguzhan Altungul ${ }^{1}$, M. Fatıh Karahuseyınoglu ${ }^{1}$ \\ ${ }^{1}$ Frrat University Sports Sciences Faculty, Elazig, Turkey \\ Correspondence: Firat University Sports Sciences Faculty, Elazıg, Turkey.
}

Received: September 6, 2017

Accepted: October 11, 2017

Online Published: October 15, 2017

doi:10.11114/jets.v5i11.2707

URL: https://doi.org/10.11114/jets.v5i11.2707

\begin{abstract}
The purpose of this study was to determine the effective factors of people choosing outdoor recreation areas, which is belonging to local government in Elazig Province Center, for feel comfortable in social, cultural and physiological aspects where they can evaluate their free time and benefit from different purposes according to different variables.

The sample group of the study consisted of 232 persons, 106 male and 126 female, selected randomly using recreational areas of local governance in Elazig province center. The data were obtained by participation preference factors for use of recreation area survey which consist 24 questions and 5 sub-dimensions that developed by Gümüs H. and Alay Özgül S. (2017) with face to face survey application method.

The data obtained from the study were analyzed using the SPSS 22 packet program. The normality test has been done so that analyzes can be done correctly. According to this, Kruskal-wallis was used in multiple groups in the analysis of data which not normal distribution and Mann Whitney-u Test was applied to determine the group which the difference occurred. In the analysis of normal distribution data, anova in multiple groups and independent samples $t$ test in binary groups were applied. Significance level was accepted as $\mathrm{p}<0.05$. There was a statistically significant difference between participants who are married and have children, who perform sports 3-4 days a week and who state their health status as good and good and sport diversity, personnel and activity sub-dimensions of the scale $(p<0.05)$. There was no statistically significant difference between the private vehicle ownership variable and participation preference for recreation areas scale $(\mathrm{p}>0,05)$.

It was determined that, for participants who married and with children, it is effective that there is playground for children in the recreational areas, the individuals who are good and very good health status are influenced by the sport diversity, activity and personnel situation in choosing these areas, private vehicle ownership is not that important for choosing these areas.
\end{abstract}

Keywords: local administration, sportive activity, recreation, participants

\section{Introduction}

In the last century, especially in the developed countries, the increase in the rate of environmental change has significantly influenced the human structure, and people are easily adapted to a life with many high-energy foods. The technological developments in transportation, automation, home, business and shopping places have significantly reduced the need for movement. While working in the workplace, driving a car, watching television are constantly occupied, cheap and accessible electronic entertainment encourages homes and makes people less active (Yıldırım et al., 2008).

The change of social and physical environment conditions has threatened human health and the level of stress has increased and it has become difficult to be happy. Today, the person who is looking for happiness and rest in the spot has turned to recreative activities because many studies in the field of recreation around the world Showed positive effects on the physical and psychological state of people and at the same time they wondered why people could not attend such important activities for psychological and physical health and this issue has been studied by many researchers (Gürbüz, Karakücük and Sarol, 2010; Badia et al. , Emir, 2012, Silver, 2012, Gürbüz and Henderson, 2014, İskender and others, 2015).

Because of the heavy burdens brought on by urban life, they are evaluating their leisure time by participating in 
open-air activities for various reasons such as getting rid of themselves, listening alone, discovering and discovering nature, meeting new people and making new friends, acquiring physical strength and strength and maintaining them and being healthy and fit. Outdoor events are held in parks in the city, in mountains outside the city, in plains, in rivers, in forests (Kalkan, 2012).

With the development and settlement of democracy consciousness, local governments become increasingly important. At present, local governments are included as villagers, municipalities and special provincial administrations. Future governments will be local governments. As a result of industrialization and urbanization, it is natural for municipalities to be front-line and to implement more important social responsibilities. Local and regional governments have played a vital role in the development of cultural events and in the realization of cultural democracies, the establishment of arts and recreation facilities (Kilbas, 2010).

In Mobley (2006), local governments and other state-owned organizations have suggested that the broad public should promote the recreational activities of interest to the public. States that the states in the United States go to the public to open their open spaces, which include their own large areas, landscapes and landscapes, beauty and historical values, and integrate with the natural environment, and local governments have taken their services and programs to places where people live.

The sport, which has an important role in the development of societies, can be traced back to the beginning of the history of humanity. Sporting activities have been and will continue to be a challenge that many people have attended and are interested in on a world scale. The mission and goals of recreation, park and leisure services should improve quality of life not only in the working life of all individuals in the society but also in the activities during their free time. This understanding carries the responsibility of both the state and local governments to improve the welfare levels of individuals (Mobley, 2006).

Regarding sports and recreation in some countries, municipal municipalities in Canada have seriously increased their activities to respond to their wishes for recreational rights of citizens by establishing municipal recreational units to undertake direct provision of a wide range of recreational and sporting services. In doing so, the municipalities inherit these services from non-profit associations such as the Youth Men's and Girls' Clubs and community recreation centers, although they are not being closed. Again, according to the survey on contributions and effects of developing sporting citizenship awareness in Canada, emotional, physical and socio-economic The right to access to sport and recreation is part of a healthy lifestyle (Harvey, 2001).

Policy changes at the local level are particularly effective in increasing physical activity in the long run by making physical activity an easier choice. For example, reducing the speed of vehicle traffic and establishing safe bike and walking routes can result in increased physical activity. It can also be argued that, when urban planning is being done, it is highly likely that people prefer to march if the land use is varied and the shops, schools, workplaces and other routes are located close to the houses (Edwards and Tsouros, 2006: 12).

Light green spaces; (Abbasi et al., 2016), which many people use on a daily basis, have no quality of life, have an effect on our physical and psychological well-being, and are available to everyone regardless of their demographic characteristics and socioeconomic status. Green spaces provide opportunities for individuals to communicate with nature and other people and offer outdoor recreational opportunities (Marjo et al., 2007; Zhang et al., 2013; Song et al., 2015).

The reasons for participation in outdoor recreational activities differ. Some people seek adventure and physical activity, some because of curiosity and awe seeking, some seeking to entertain nature and learn about nature, and others seeking to escape and regenerate daily routines (Driver et al., 1991; Driver et al., 1996; Lekies Et al., 2015) participate in recreational activities.

The purpose of this study was to determine the effective factors in choosing open air recreation areas of local governments where they would feel comfortable in social, cultural and physiological terms and where they could benefit from different purposes in Elazıg province center where they can evaluate their leisure time.

\section{Materials and Methods}

The purpose of the study was to determine the effective factors in choosing open air recreation areas of local governments where they would feel comfortable in social, cultural and physiological sense and to benefit from different purposes according to different demographic characteristics in Elazig province center where people can evaluate their leisure time.

The sample group of the study consisted of 232 people, 106 male and 126 female, who were randomly selected using local management recreation areas in Elazıg province center. 
The data of the study were collected with the scale of participation preference factors related to the use of the recreation area, which consisted of 24 questions and 5 sub-dimensions developed by Gümüs, H., and Alay Özgül, S. (2017). The data obtained from the study were analyzed using the SPSS 22 packet program. The normality test has been done so that the analyzes can be done correctly. Kruskal-wallis was used in multiple groups in the analysis of data with no normal distribution and the Mann Whitney-u Test was used to determine the group in which the difference occurred. In the analysis of normal distribution data, anova was used in multiple groups and independent samples t test was applied in binary groups. The level of significance was accepted as $\mathrm{p}<0.05$

\section{Results}

Table 1. Descriptive information of participants

\begin{tabular}{|c|c|c|}
\hline & $\mathrm{N}$ & $\%$ \\
\hline \multicolumn{3}{|l|}{ Gender } \\
\hline \multirow{2}{*}{$\begin{array}{l}\text { Male } \\
\text { Woman }\end{array}$} & 106 & 45,7 \\
\hline & 126 & 54,3 \\
\hline \multicolumn{3}{|l|}{ Age } \\
\hline \multirow{5}{*}{$\begin{array}{l}18-24 \\
25-31 \\
32-38 \\
39-45 \\
46 \text { and over }\end{array}$} & 40 & 17,3 \\
\hline & 71 & 30,6 \\
\hline & 63 & 27,2 \\
\hline & 26 & 11,3 \\
\hline & 32 & 13,6 \\
\hline \multicolumn{3}{|l|}{ Income } \\
\hline \multirow{5}{*}{$\begin{array}{l}0-500 \\
501-1000 \\
1001-2000 \\
2001-3000 \\
3001 \text { and over }\end{array}$} & 42 & 18,1 \\
\hline & 32 & 13,8 \\
\hline & 84 & 36,2 \\
\hline & 53 & 22,8 \\
\hline & 21 & 9,1 \\
\hline \multicolumn{3}{|l|}{ Education Status } \\
\hline \multirow{5}{*}{$\begin{array}{l}\text { Primary school } \\
\text { Middle School } \\
\text { High school } \\
\text { University } \\
\text { Graduate }\end{array}$} & 16 & 6,9 \\
\hline & 22 & 9,5 \\
\hline & 76 & 32,8 \\
\hline & 114 & 49,1 \\
\hline & 4 & 1,6 \\
\hline \multicolumn{3}{|l|}{ Marital status } \\
\hline \multirow{3}{*}{$\begin{array}{l}\text { Married, with Children } \\
\text { Married, no children } \\
\text { Single-Childless }\end{array}$} & 79 & 34,1 \\
\hline & 33 & 14,2 \\
\hline & 120 & 51,7 \\
\hline Total & 232 & 100 \\
\hline
\end{tabular}

Looking at Table 1, $54.3 \%$ of the respondents were female and $45.7 \%$ were male. When the distribution of the participants among the age groups is examined, it is found that $17.3 \%$ of the participants are $18-24$ years old, $30.6 \%$ are 25-31 years old, 27.2\% are 32-38 years old, $11.3 \%$ And $13.6 \%$ of them are over 46 years old. According to the income status, $18,1 \%$ is between $0-500 \mathrm{TL}, 13,8 \%$ is between $501-1000 \mathrm{TL}, 36,2 \%$ is between $1001-2000 \mathrm{TL}, 22,8 \%$ is between 2001-3000 TL, 9\%, 1 of them have an income status of TL 3001 or more.

When the educational status of the participants is examined, it is seen that $6.9 \%$ is in primary school, $9.5 \%$ is in secondary school, $32.8 \%$ is in high school, $49.1 \%$ is in university and $1.6 \% 34,1 \%$ were married-children, $14,2 \%$ were married-without children and $51,7 \%$ were single-childless. Single-childless. 
Table 2. Participants' specific vehicle, frequency of sports and general health status

\begin{tabular}{|c|c|c|}
\hline Special Vehicle & $\mathbf{N}$ & $\%$ \\
\hline Yes & 78 & 33,6 \\
\hline No & 154 & 66,4 \\
\hline \multicolumn{3}{|c|}{$\begin{array}{l}\text { The frequency of doing } \\
\text { sports (Weekly) }\end{array}$} \\
\hline \multirow{4}{*}{$\begin{array}{l}1 \\
2 \\
3 \\
4\end{array}$} & 93 & 40,1 \\
\hline & 51 & 21,7 \\
\hline & 72 & 31,5 \\
\hline & 16 & 6,7 \\
\hline \multicolumn{3}{|c|}{ General health status } \\
\hline \multirow{6}{*}{$\begin{array}{l}\text { Bad } \\
\text { Not bad } \\
\text { I am not sure } \\
\text { Good } \\
\text { Very good } \\
\quad \text { Excellent }\end{array}$} & 2 & 0,9 \\
\hline & 32 & 13,8 \\
\hline & 30 & 12,8 \\
\hline & 131 & 56,5 \\
\hline & 35 & 15,1 \\
\hline & 2 & 0,9 \\
\hline Total & 232 & 100 \\
\hline
\end{tabular}

Looking at Table 2, it is seen that $33.6 \%$ of the respondents have a mediocre and $66.4 \%$ have not. It was determined that $40.1 \%$ of the sportsmen played 1 day a week, $21.7 \%$ of sportsmen played 2 days a week, $31.5 \%$ of sportsmen played 3 days a week and $6.7 \%$ of sportsmen played 4 days a week. Participants rated their overall health status as poor by $0.9 \%$, not as bad as $13.8 \%$, not as good as $12.8 \%$, well as $56.5 \%$, excellent as $15.1 \%$ and $0.9 \%$ as excellent.

Table 3. Anova test results of participants 'marital status change and recreation areas

\begin{tabular}{|c|c|c|c|c|c|}
\hline \multirow[t]{3}{*}{ Sportive diversity } & Married, children & $13,53^{*}$ & 1,24 & \multirow{3}{*}{4,33} & \multirow{3}{*}{0,014} \\
\hline & Married, children & 13,24 & 1,75 & & \\
\hline & Single-children & 12,84 & 1,81 & & \\
\hline \multirow{3}{*}{ Personnel } & Married, children & 17,81 & 1,94 & \multirow{3}{*}{2,14} & \multirow{3}{*}{0,120} \\
\hline & Married, children & 17,21 & 1,88 & & \\
\hline & Single-children & 17,14 & 2,57 & & \\
\hline \multirow{3}{*}{ Position } & Married, children & 12,40 & 1,67 & \multirow{3}{*}{0,79} & \multirow{3}{*}{0,453} \\
\hline & Married, children & 12,60 & 1,57 & & \\
\hline & Single-children & 12,73 & 1,92 & & \\
\hline \multirow{3}{*}{$\begin{array}{l}\text { Physical } \\
\text { competence }\end{array}$} & Married, children & 39,22 & 3,70 & \multirow{3}{*}{2,18} & \multirow{3}{*}{0,115} \\
\hline & Married, children & 38,39 & 3,81 & & \\
\hline & Single-children & 38,00 & 4,25 & & \\
\hline \multirow{3}{*}{$\begin{array}{l}\text { Physical } \\
\text { competence }\end{array}$} & Married, children & $20,60 *$ & 2,74 & \multirow{3}{*}{5,54} & \multirow{3}{*}{0,004} \\
\hline & Married, children & 18,48 & 3,61 & & \\
\hline & Single-children & 19,39 & 3,63 & & \\
\hline
\end{tabular}

In Table 3, when looking at the relationship between the marital status of the participants and the preference factors of the recreational areas, the married-childless individuals were found to have marital-childless and single-childless marriages and sportive diversity and activity sub-dimensions in favor of married- Was found to be a statistically significant differentiation. It has been found that there is no difference between the staff, location and physical competence sub-dimensions of the scale and the marital status of the participants.

Table 4. Results of the t-test for the relationship between participants 'preference for mediating variable and recreation areas' preferred factors scale

\begin{tabular}{|c|c|c|c|c|c|c|}
\hline & Special Vehicle & N... & Average Score & Ss & t & $\mathbf{p}$ \\
\hline Sportive diversity & $\begin{array}{l}\text { Yes } \\
\text { No }\end{array}$ & $\begin{array}{c}78 \\
154\end{array}$ & $\begin{array}{l}12,65 \\
12,87\end{array}$ & $\begin{array}{l}1,83 \\
1,89\end{array}$ & ,008 & 0,061 \\
\hline Personnel & $\begin{array}{l}\text { Yes } \\
\text { No }\end{array}$ & $\begin{array}{c}78 \\
154 \\
\end{array}$ & $\begin{array}{l}17,57 \\
17,27 \\
\end{array}$ & $\begin{array}{l}2,64 \\
2,10 \\
\end{array}$ & ,932 & 0,352 \\
\hline Position & $\begin{array}{l}\text { Yes } \\
\text { No }\end{array}$ & $\begin{array}{c}78 \\
154 \\
\end{array}$ & $\begin{array}{l}12,60 \\
12,60 \\
\end{array}$ & $\begin{array}{l}1,79 \\
1,80 \\
\end{array}$ & ,006 & 0,996 \\
\hline Physical competence & $\begin{array}{l}\text { Yes } \\
\text { No }\end{array}$ & $\begin{array}{c}78 \\
154 \\
\end{array}$ & $\begin{array}{l}38,62 \\
38,41 \\
\end{array}$ & $\begin{array}{l}4,01 \\
4,04 \\
\end{array}$ &, 365 & 0,716 \\
\hline Physical competence & $\begin{array}{l}\text { Yes } \\
\text { No }\end{array}$ & $\begin{array}{c}78 \\
154\end{array}$ & $\begin{array}{l}19,80 \\
19,11\end{array}$ & $\begin{array}{l}2,89 \\
2,42\end{array}$ & ,976 & 0,425 \\
\hline
\end{tabular}


There was no statistically significant difference $(p>0,05)$ between all subscales of the scale and the state of having intermediate between when the participants had a particular mediating role and the choice of recreation areas (table 4).

Table 5. Results of variance analysis of participants' frequency of weekly variation of sport and preference of recreation areas

\begin{tabular}{|c|c|c|c|c|c|c|}
\hline & The frequency of doing sports (Weekly ) & & & & & \\
\hline & & $\mathbf{N}$ & Average Score & Ss & f & $\mathbf{p}$ \\
\hline Sportive diversity & 1 day & 93 & & & & \\
\hline & 2 day & 50 & 13,13 & 1,65 & 11,59 & 0,009 \\
\hline & 3 day & 73 & & & & \\
\hline & 4 day & 16 & & & & \\
\hline Personnel & 1 day & 93 & & & & \\
\hline & 2 day & 50 & 17,37 & 2,29 & 3,97 & 0,265 \\
\hline & 3 day & 73 & & & & \\
\hline & 4 day & 16 & & & & \\
\hline Position & 1 day & 93 & & & & \\
\hline & 2 day & 50 & 12,60 & 1,79 & 5,20 & 0,157 \\
\hline & 3 day & 73 & & & & \\
\hline & 4 day & 16 & & & & \\
\hline Physical competence & 1 day & 93 & & & & \\
\hline & 2 day & 50 & 38,48 & 4,02 & 1,70 & 0,635 \\
\hline & 3 day & 73 & & & & \\
\hline & 4 day & 16 & & & & \\
\hline Physical competence & 1day & 93 & & & & \\
\hline & 2 day & 50 & 19,68 & 3,41 & 13,50 & 0,004 \\
\hline & 3 day & 73 & & & & \\
\hline & 4 day & 16 & & & & \\
\hline & Total & 232 & & & & \\
\hline
\end{tabular}

When the frequency of weekly sports activities of the participants was examined, it was determined that 93 people were participating in the sport for 1 day, 50 participants for 2 days, 73 participants for 3 days and 16 participants for 4 days a week (table 5).

Table 6. Results of the Mann Whitney-U Test to test the significance of the difference between the participants' preference for recreational areas and weekly sports frequency

\begin{tabular}{llllll}
\hline $\begin{array}{l}\text { Sportive } \\
\text { diversity }\end{array}$ & $\begin{array}{l}\text { The } \\
\text { frequency of } \\
\text { doing sports } \\
\text { (Weekly) }\end{array}$ & $\begin{array}{l}\text { Order } \\
\text { average }\end{array}$ & U & $\mathrm{z}$ & $\mathrm{p}$ \\
\cline { 2 - 6 } & $\begin{array}{l}\text { 1 day } \\
\text { 3 day }\end{array}$ & $\begin{array}{l}75,93 \\
93,14\end{array}$ & 2690,500 & $-2,341$ & 0,019 \\
\hline Activity & 1 day & 74,24 & & & \\
& 3 day & 91,04 & 2552,000 & $-2,269$ & 0,023 \\
\hline
\end{tabular}

In Table 6, non-parametric Mann Whitney-U test was used to determine whether there was a meaningful difference between the sportive diversity and activity subscales of the scale and the frequency of sporting activities. There was a statistically significant difference at $\mathrm{p}<0.05$ respectively.

Table 7. Results of the Mann Whitney-U Test to test the significance of the difference between the participants' preference for recreational areas according to the frequency of weekly sports activities

\begin{tabular}{|c|c|c|c|c|c|}
\hline \multirow[t]{3}{*}{$\begin{array}{l}\text { Sportive } \\
\text { diversity }\end{array}$} & $\begin{array}{l}\text { The } \\
\text { frequency of } \\
\text { doing sports } \\
\text { (Weekly) }\end{array}$ & $\begin{array}{l}\text { Order } \\
\text { average }\end{array}$ & $\mathrm{U}$ & $\mathrm{z}$ & $\mathrm{p}$ \\
\hline & 1 day & 51,59 & & & \\
\hline & 4 day & 74,84 & 426,500 & $-2,778$ & 0,005 \\
\hline \multirow[t]{2}{*}{ Activity } & 1 day & 50,29 & & & \\
\hline & 4 day & 78,69 & 349,000 & $-3,365$ & 0,001 \\
\hline
\end{tabular}

Table 7 shows the results of non-parametric Mann Whitney-U test, which showed that there was a difference in the sportive diversity and activity subscales between those who played sports for 4 days a week and those who sport for 4 days a week at a level of $\mathrm{p}<0,05 \mathrm{He}$ was put. 
Table 8. Results of variance analysis of the associations between general health status variables and recreation areas

\begin{tabular}{|c|c|c|c|c|c|c|}
\hline \multirow[t]{6}{*}{ Sportive diversity } & bad & 2 & \multirow{6}{*}{13,1336} & \multirow{6}{*}{1,65780} & \multirow{6}{*}{13,983} & \multirow{6}{*}{0,016} \\
\hline & not bad & 32 & & & & \\
\hline & I am not sure & 30 & & & & \\
\hline & good & 131 & & & & \\
\hline & very good & 35 & & & & \\
\hline & excellent & 2 & & & & \\
\hline \multirow[t]{6}{*}{ Personnel } & bad & 2 & \multirow{6}{*}{17,3793} & \multirow{6}{*}{2,29683} & \multirow{6}{*}{18,156} & \multirow{6}{*}{0,003} \\
\hline & not bad & 32 & & & & \\
\hline & I am not sure & 30 & & & & \\
\hline & good & 131 & & & & \\
\hline & very good & 35 & & & & \\
\hline & excellent & 2 & & & & \\
\hline \multirow[t]{6}{*}{ Position } & bad & 2 & \multirow{6}{*}{12,6034} & \multirow{6}{*}{1,79648} & \multirow{6}{*}{4,286} & \multirow{6}{*}{0,509} \\
\hline & not bad & 32 & & & & \\
\hline & I am not sure & 30 & & & & \\
\hline & good & 131 & & & & \\
\hline & very good & 35 & & & & \\
\hline & excellent & 2 & & & & \\
\hline \multirow{6}{*}{$\begin{array}{l}\text { Physical } \\
\text { competence }\end{array}$} & bad & 2 & \multirow{6}{*}{38,4868} & \multirow{6}{*}{4,02906} & \multirow{6}{*}{8,148} & \multirow{6}{*}{0,148} \\
\hline & not bad & 32 & & & & \\
\hline & I am not sure & 30 & & & & \\
\hline & good & 131 & & & & \\
\hline & very good & 35 & & & & \\
\hline & excellent & 2 & & & & \\
\hline \multirow{7}{*}{$\begin{array}{l}\text { Physical } \\
\text { competence }\end{array}$} & bad & 2 & \multirow{7}{*}{19,6842} & \multirow{7}{*}{3,41496} & \multirow{7}{*}{14,468} & \multirow{7}{*}{0,013} \\
\hline & not bad & 32 & & & & \\
\hline & I am not sure & 30 & & & & \\
\hline & good & 131 & & & & \\
\hline & very good & 35 & & & & \\
\hline & excellent & 2 & & & & \\
\hline & Total & 232 & & & & \\
\hline
\end{tabular}

When we looked at the general health status of the participants, it was determined that the health condition was worse for 2, 32 for worse, 30 for unsure, 31 for good, 35 for very good and 2 for health (Table 8).

Table 9. Results of the Mann Whitney-U Test to test the significance of the difference between the participants' recreational areas preference scale and the general health status variable

\begin{tabular}{llllll}
\hline & Health Status & Order average & $\mathrm{U}$ & $\mathrm{z}$ & $\mathrm{p}$ \\
\hline Sportive diversity & not bad & 60,03 & 1393,000 & $-3,000$ & 0,003 \\
& good & 87,37 & & & \\
Activity & not bad & 64,55 & 1537,500 & $-2,188$ & 0,029 \\
& good & 84,49 & & & \\
\hline
\end{tabular}

Table 9 shows that there was a statistically significant difference of $p<0.05$ compared to the results of the non-parametric Mann Whitney-U test between the sporty diversity and activity subscales of the participants who stated that the health status was good in the participants and those who were not healthy, and that this significant difference Health status as good for those who have been determined.

Table 10. Results of the Mann Whitney-U Test to test the significance of the difference between the participants' preference for recreation areas according to the general health status variable

\begin{tabular}{llllll}
\hline & Health Status & Order average & $\mathrm{U}$ & $\mathrm{z}$ & $\mathrm{p}$ \\
\hline \multirow{2}{*}{ Sportive diversity } & not bad & 27,56 & 354,000 & $-2,636$ & 0,008 \\
& good & 39,89 & & & \\
staff & not bad & 25,83 & 298,500 & $-3,358$ & 0,001 \\
\multirow{4}{*}{ activity } & good & 41,47 & & & \\
& not bad & 25,47 & 287,000 & $-3,315$ & 0,001 \\
& good & 41,06 & & & \\
\hline
\end{tabular}

Looking at Table 10, it was seen that there was a significant difference in the statistical level of sport diversity, staff and activity subscales between those who declared general health status as not bad and very good, and those who had very good health status at statistical level. 


\section{Discussion and Conclusion}

With rapidly increasing populations and housing numbers, people need recreation and park areas where they can feel more comfortable both spiritually and physically. In this part of the study, participants were asked to discuss the relationship between the findings of the variables such as marital status, state of having mediocre, weekly sports making frequency and general health status, and preference factors of recreation areas.

The marital status of those who were married and those who were children was found to be significantly different in favor of married and childless married-unmarried and single-childless married and children with sportive diversity and activity subscales. According to a study done, the participants who are married stated that it is possible for them to be able to live a good quality leisure time and to be able to play sports, and also to improve the existing policies, in order to be able to live the healthy future of their future as well (Birol S.Ş., Karaküçük S, 2014) The study yielded results in the same way as we investigated individuals' ability to do sports.

In a different study, there are no significant differences between marital status, child ownership and recreational tourism enterprises and the frequency of visits (Orel Demirci F, Yavuz M.C, 2003) the study yielded different results with our research. It can be said that marital and married individuals have more participation in choosing recreational areas of local governments, indicating that sportive diversity and activity are important (table 3). There was no significant difference between the participants' preference for locally owned recreational areas. The second important factor in the reasons for choosing the recreational activities offered by the municipality in the survey is the "ease of transportation" factor. According to this reason, the reasons for preferring activities are close to home when weighing on the materials, the easiness of transportation and the factors are more foreground. (Arslan S, 2012) Although there is no significant difference between our possession of intermediaries and choosing recreation areas However, it is thought that the convenience of transportation in choosing the recreation areas of the individuals and the close proximity of these areas to their homes is also an important factor in the central location (table 4).

When we look at the percentage distribution of the levels of importance given to the features expected from recreational service operation in a study conducted, individuals indicated that $88.0 \%$ of them see sporting facilities at a significant level. In the same study, it was determined that the demand for individual participation in cultural and social activities as an activity is as high as $83.9 \%$. (Orel Demirci F, Yavuz MC, 2003). In a particular study, participants reported a lack of recreation in urban recreation areas, the highest rate of activity inadequacy was $20.3 \%$, and the percentage of inadequate play and sports areas was $15.5 \%$, the percentage of those who saw cycling, running, and 13.4. (Talay, et al., 2010). The participants who use recreational areas in our research and those who exercise weekly for 3 or 4 days and those who play sports for 1 day have higher scores on sports diversity and activity subscales than those who have higher sports people, It can be said that the diversity of sports fields and activities is important for individuals to choose these areas (Table 6-7).

Participants who stated that their health status was good and very good in our research were found to have a higher score in sportive diversity, activity, and personnel subscales according to participants who also stated their health status as not bad (Table 9-10).

It has been determined that there is a relationship between the physical activity of people in their free time and the parameters of low obesity risk, preventable chronic diseases and prepatient death. It has been determined in some studies that active leisure, which has spent its leisure time doing physical activity at the same time, has an effect on physical health with unobserved factors such as enjoyment, time preference, time cost (Komlos et al., 2004, Smith et al., 2005).

Ertiizün E, (2016) notes that sportive recreational activities are based on volunteerism and enjoyment, so they have an important effect on preventing disease, protecting and improving health, and that people are willing to participate in sportive recreational activities that motivate people to be active, while at the same time spiritually satisfying he stated.

If we look at the results obtained from our studies and researches; It has been found that marital and married individuals prefer local managed recreational areas, and that having various sporting activities and activities is important for children in these areas. Particularity of the participants is not statistically significant, but it is important that the recreation areas are close to their homes and that public transportation is available. Participants were found to be in favor of those who had more frequent weekly sports activities in recreation areas where sportive diversity and activities were present. Participants using locally managed recreational areas have found that health status is an effective component of the well-being and the well-being of the sportive diversity, activities and staff in choosing recreational areas for the very best. 


\section{References}

Abbasi, A., Alalouch, C., \& Bramley, G. (2016). Open Space Quality In Deprived Urban Areas: User Perspective and Use Pattern. Procedia-Socia land Behavioral Sciences, 216, 194-205. https://doi.org/10.1016/j.sbspro.2015.12.028

Arslan, S. (2012). Analysis of Factors Affecting Recreational Preferences of Urban Individuals: Ankara Metropolitan Municipality Example, IIBB International Refereed Academic Social Sciences Journal Special, 2(03), 07.

Badia, M., Orgaz, B. M., Verdugo, M. A., Ullan, M. A., \& Martinez, M. M. (2011). Personal factors and perceived barriers to participation in leisure activities for young and adults with developmental disabilities. Research in Developmental Disabilities, (32), 2055-2063. https://doi.org/10.1016/j.ridd.2011.08.007

Birol, S., \& Karaküçük, S, (2014). A Study on Sportive Recreation Application Policies KMÜ Social and Economic Research Journal 16 (27), 80-86, 2014 ISSN: 2147-7833.

Driver, B. L., Manfredo, M. J., \& Tarrant, M. (1996). Measuring Leisure Motivations: A Meta-Analysis of the Recreation Experience Preference Scales. Journal of Leisure Research, 28,188-213.

Driver, B. L., Tinsley, H., \& Manfredo, M. J. (1991). Results from Two Inventories Designed to Assess the Breadth of the Perceived Psychological Benefits of Leisure, In: B.L. Driver, P.J. Brown, and G.L. Peterson (Eds.), Benefits of leisure State College, PA: Venture Publishing, Inc., 263-286.

Edwards, Peggy-Tsouros, A. (2006). Promoting Physical Activity and Active Living in Urban Environments: The Role of, Publications WHO Regional Office for Europe Scherfigsvej 8 DK-2100 Copenhagen, Denmark.

Emir, E. (2012). Determination of obstacles before participation in recreational activities: example of university students. Unpublished Master's Thesis, Karadeniz Technical University, Trabzon.

Ertüzün, E. (2016). Recreation and Well-being from a Health Perspective, Science of Recreation (From) Ankara. Gazi Bookstore, 555-557.

Gumus, H. (2012). Factors affecting location selection and activity participation of users who come to park and recreation areas for physical activity. Unpublished Master's Thesis, Gazi University, Faculty of Health Sciences, Ankara.

Gumus, H., \& Alay, Ö. S. (2017). Development of participation barriers and preference factors scales for recreation area use. Journal of Human Sciences, 14(1), 865-882. https://doi.org/10.14687/jhs.v14i1.4448

Gurbuz, B., \& Henderson, K. A. (2014). Leisure activity preferences and constraints: Perspectives from Turkey. Word Leisure Journal, 56(4), 300-316. https://doi.org/10.1080/16078055.2014.958195

Gurbuz, B., Karakucuk, S., \& Sarol, H. (2010). Examination of perceived obstacle differences before participation in recreational activities. 11th International Sports Science Congress, 340-343, 10-12 November, Antalya.

Harvey, J. (2001). "The Role of Sport and Recreation Policy in Fostering Citizenship: The Canadian Experience", Canadian Policy Research Networks Inc. (CPRN), 600-250 Albert Street, Ottawa, Ontario K1P 6M1, CPRN Discussion Paper No. F|17, 23-45.

İskender, A., Avc1, C., \& Yaylı, A. (2015). Determining participation levels of recreational activities as a leisure time evaluation tool for young people. Journal of Recreation and Tourism Research, 2(1), 36-42.

Kalkan, A. (2012). Outdoor recreation, the reasons why individuals who play nature sports do these sports: Antalya example. Master Thesis, Akdeniz University, Antalya.

Kılbas, Ş. (2010). Recreation Leisure Review, Gazi Kitabevi, Ankara p: 284

Komlos, J., Smith, P. K., \& Bogin, B. (2004). Obesity and there rate of time preference: is there a connection? Journal of Biosocial Science, 36(2), 209-219. https://doi.org/10.1017/S0021932003006205

Lekies, K. S., Yost, G., \& Rode, J. (2015). Urban youth's Experiences of Nature: Implications for Outdoor Adventure Recreation. Journal of Outdoor Recreation and Tourism, 9, 1-10. https://doi.org/10.1016/j.jort.2015.03.002

Marjo, N., Tuija, S., Susan, T., \& Terhi, K. (2007). Access to Green Area sand the Frequency of Visits-A Case Study in Helsinki. Urban Forestry and Urban Greening, 6(4), 235-247. https://doi.org/10.1016/j.ufug.2007.05.003

Mobley, T. (2006). The role of local governments in meeting people's needs for recreation and parking. 27-28 April 2006, Healthy Cities Association Meeting, Eskisehir.

Orel, D. F., \& Yavuz, M. C. (2003). A Pilot for Determining the Customer Potential in Recreational Tourism Cukurova University Journal of Social Sciences Institute, 11.

Smith, P. K., Bogin, B., \& Bishai, D. (2005). Are time preference and body mass index as sociated?: Evidence from the 
National on gitudinal Survey of Youth. Economics\& Human Biology, 3(2), 259-270. https://doi.org/10.1016/j.ehb.2005.05.001

Song, X., Lv, X. B., \& Li, C. (2015). Willingness and Motivation of Residents to Pay for Conservation of Urban Green Spaces in Jinan, China. Acta Ecologica Sinica, 35(4), 89-94. https://doi.org/10.1016/j.chnaes.2015.06.003

Talay, I., Kaya, F., \& Belkayalı, N. (2010). The Effect of Socio-Economic Structure on Recreational Tendency and Demands: Bartın City Case, Journal of Geographical Sciences CBD, 8(2), 147-156.

Tamer, K. (1998). Leading behavioral dimensions of coaches leading to sporting recreational activities. Gazi University, Institute of Health Sciences, Department of Physical Education and Sports, Graduate Thesis, Ankara.

Y1ldırım, M., Akyol, A., \& Ersoy, G. (2008). Obesity and Physical Activity, a Look at Activity of the Energy Balance. Ankara: Klasmat Publishing House, Ministry of Health Publication No: 729.

Zhang, H., Chen, B., Sun, Z., \& Bao, Z. Y. (2013). Land scape Perception and Recreation Needs in Urban Green Spaces in Fuyang, Hangzhou, China. Urban Forestry and Urban Greening, 12(1), 44-52. https://doi.org/10.1016/j.ufug.2012.11.001

\section{Copyrights}

Copyright for this article is retained by the author(s), with first publication rights granted to the journal.

This is an open-access article distributed under the terms and conditions of the Creative Commons Attribution license which permits unrestricted use, distribution, and reproduction in any medium, provided the original work is properly cited. 